\title{
The Geography of Same-Sex Desire \\ Cruising Men in Washington, DC in the Late Nineteenth and Early Twentieth Centuries
}

\section{Brett Beemyn}

For years and years I have been this way - have loved and worshipped silently other boys and youths, some older, some younger than myself - sexual inversion, Havelock Ellis calls it .... I never thought I should write anything like this down but here it is done.

"Jeb Alexander," diary entry, 11 February $1921^{1}$

It occurred to me today with something of a shock how horrible it would be for this diary of mine to be pawed over and read unsympathetically by friends or relatives after I am dead, by those utterly incapable of understanding, who would be filled with disgust and astonishment and think of me as a poor perverted wretch, a neurotic or a madman who was better off dead. And then the thought of the one thing even more dreadful and terrible than that - for my diary never to be read by the one person who could or would understand. For I do want it to be read - there is no use concealing the fact - by somebody who is like me, who would understand absolutely and yet Havelock Ellis is about the only person known to me, that is known by name, to whom I could confidently entrust this record of my life.

"Jeb Alexander," diary entry, 16 April 1923

Men who documented their same-sex sexual experiences in the late nineteenth and early twentieth centuries faced ostracism should their writing be discovered during their lifetimes, or the likelihood that they would be remembered with shame should it be found after their deaths - with surviving family members then either destroying their work or hiding it away. Given these circumstances, it is not surprising that relatively few primary sources exist which describe how men in the US pursued same-sex relationships at the time, either in the nation's capital or in other cities, and how they developed social spaces in which to do so. ${ }^{2}$ It is this lack of first-hand material that makes the diaries of "Jeb Alexander," a white, middle-class Washingtonian born at the turn of the twentieth century, so important. Recognizing that the silencing of his voice would be more detrimental than a hostile reaction, Alexander extensively doc-

141

(c) Left History

9.2 (Spring/Summer 2004) 


\section{Beemyn}

umented his sexual experiences in the capital, including the different sites and techniques utilized for "cruising" - a term he used as early as 1923 to refer to his attempts to find sexual partners - and the harassment practices of the police and larger society. ${ }^{3}$ More than any other single source, his regular diary entries establish the parameters of white male same-sex sexuality in Washington, DC in the early 1900 s.

Drawing from Alexander's diaries, this essay will explore how men who pursued same-sex relationships navigated Washington's sexual landscape, which was often defined by the color line. Although Washington did not enact segregation laws like many southern states, racial discrimination in public facilities was a firmly entrenched practice in the capital by the turn of the twentieth century. ${ }^{4}$ Thus some of the principal locations where men met each other for sexual relationships in downtown Washington - movie theaters, clubs, restaurants, apartment and rooming houses, and the YMCA - restricted the access of African Americans or denied them admittance altogether. As a result, Black men hoping to meet other men for sexual encounters, like African Americans in general, lived and socialized primarily within the city's Black neighborhoods of Shaw, U Street, and Georgia Avenue.

A number of community histories have examined male same-sex sexuality prior to World War II, including George Chauncey's Gay New York: Gender, Urban Culture, and the Making of the Gay Male World, 1890-1940 and essays on Chicago by David K. Johnson and Allen Drexel in my anthology Creating a Place for Ourselves: Lesbian, Gay, and Bisexual Community Histories. But few works have considered the social and sexual lives of Black and white men in a thoroughly segregated society. ${ }^{5}$ The one major study of men who desired men in a segregated community, John Howard's Men Like That: A Southern Queer History, examines post-World War II Mississippi, a society much less urban and more racially polarized than Washington. According to Howard, in Mississippi, "black men and white men participated in markedly similar worlds of desire that rarely overlapped before the 1960s." In the nation's capital, though, the creation of these separate worlds did not preclude some racial mixing in the early twentieth century, particularly in the extensive park land in downtown Washington, which was not segregated, and in parts of the city's tenderloin district, which enforced racial separation but not always rigidly.

Washington thus represents something of a middle ground between communities in the Northeast and Midwest, where men, particularly white men, who desired same-sex partners could often readily cross racial lines, and communities further South, where interracial socializing, much less sexual relationships, was heavily proscribed. While racism excluded African Americans from many downtown Washington institutions and kept most whites from patronizing establishments in the city's Black neighborhoods in the late nineteenth and early twentieth centuries, white and Black men attracted to others of 
the same sex created spaces in which both groups could co-exist and where some men had relationships across racial lines. In Alexander's case, racism led him to avoid Black men whenever he could. But the fact that he had to create his own all-white sexual world demonstrates the potential for racial mixing, as well as the extent of racial separation, in the nation's capital.

"Meet me by the White House": adventures in the city's parks

It was a lovely night to sit in the peaceful confines (outwardly peaceful, to those who don't know the passion and intrigue and mystery sheltered in those dim shades) of Lafayette Square

"Jeb Alexander," diary entry, 14 September 1922

For Alexander, cruising in the city's parks, particularly in the "dim shades" of Lafayette Square across from the White House, was nearly a nightly ritual each spring and summer during the early 1920 s. He would go "as soon as darkness fell" and stay until "things had grown very quiet" between eleven and midnight, hoping to find the "lasting ideal friend ... [he] had dreamed of so often."7 But despite the frequency and duration of his visits, Alexander largely failed in his attempts to pick up men, much less to develop a long-term relationship, because he rarely had enough courage to approach others, even those who seemed interested in him - a reluctance he called his "curse." Alexander's frustrating experiences made Lafayette Square seem especially enticing, causing him to "feel that [he was] missing something" if he did not go every night. ${ }^{8}$

Cruising was far from entirely futile for Alexander, though; after several years of looking for sexual partners, he began to overcome his fears and shyness. At the back of his diaries, he kept lists of all the men he met, when and often where he encountered them, and the sex acts in which they engaged. ${ }^{9}$ For 1920 , Alexander recorded what he referred to as "adventures" with three men he met in the city's parks. In 1921, he had four; the following year there were six; and in 1923 - the last year that he regularly went cruising - he had more than twenty different sexual encounters. Most were one-night affairs and, for all of his trips to the parks, Alexander never had sex with anyone more than four times, despite seeing some of the same men nearly every evening. One such man was Henry Gerber, whom Alexander viewed as a nuisance because Gerber would initiate conversations with him even after Alexander had made it clear that he was no longer interested in him. ${ }^{10}$ Soon after being turned down by Alexander, Gerber returned to his Chicago home and helped found the shortlived Society for Human Rights, the first known homophile organization in the US. ${ }^{11}$

Alexander provided descriptions of many of the men he saw in the parks, 
most of whom were well-dressed whites from their late teens to early thirties. This may have reflected his interest in meeting only young, middle-class whites who were "not obvious," although he did mention the men of color, the older men, and the "poorly dressed" whom he ignored or rejected outright. ${ }^{12}$ Most of the men he had sex with worked in professional occupations in or near Washington; among them were a doctor, a reporter for the Washington Herald, a bank employee, an auditor for the Department of Agriculture, and an office apprentice at the Bureau of Standards. Alexander himself worked for many years as an editor for a federal agency.

All of Alexander's sexual partners seem to have been white because of his racist attitudes, which he openly expressed throughout his diaries. He regularly referred to African Americans using racial epithets, for example, and recounted how he lost his appetite at a New York City restaurant while on vacation in 1923 when he saw a Black man eating at a nearby table. ${ }^{13}$ Given that almost all of Washington's downtown facilities discriminated against African Americans, it was probably one of the first times that he had been in a cafeteria that was not all-white. The prevalence of racism and segregation, however, did not prevent Black men from meeting whites and each other in the District's parks, especially late at night. In fact, some of the earliest arrests for same-sex sexual activity in Washington were of Black men, such as the apprehension of eighteen men - the majority of whom were African American - for engaging in oral sex in Lafayette Square in $1892 .{ }^{14}$ Cruising among Black men was also quite common in the early twentieth century, as demonstrated by the fact that Alexander referred to a bench in Lafayette Square as "the Nigger's Bench" because one or more African Americans regularly sat there. ${ }^{15}$

In order to make pick-ups, Alexander initially sat for hours in Lafayette Square on one of several well-situated benches, which he called "the Wishing Bench", "the Magnolia Bench", and "Nighthawk's Bench" (after the name he gave someone who often sat there), and waited for other men to come to him. But when few men approached, one of Alexander's first sexual partners advised him to take the initiative in meeting men by making tours of the park, rather than just waiting for someone to sit beside him. Thereafter, Alexander developed a routine of periodically walking through Lafayette Square and on nearby streets, particularly Pennsylvania Avenue and 9th and F Streets, which he described as "the three streets whereon life concentrates."16 If he saw someone he found attractive, Alexander would sit on a nearby bench and try to determine whether the man might be interested in him by gaining the person's attention. He still rarely approached anyone directly, reflecting a lingering shyness despite his numerous trips to the parks.

Although Lafayette Square was the main public cruising area in Washington, at least since 1885 , when it began to stay open all night, it was not the only location where men interested in same-sex relationships met one 
another. ${ }^{17}$ Park police records for the early 1900 s indicate that officers made arrests for "indecent assault" - the typical charge for consensual same-sex sexual activity short of sodomy - in many of the city's parks, including the Smithsonian Grounds (the Mall) and nearby Franklin Park and Judiciary Square. ${ }^{18}$ In his diaries, Alexander notes that he occasionally met men in Franklin Park, as well as in Farragut Square and the Washington Monument Grounds. But more often he would make a pick-up in Lafayette Square and the two would walk to a more secluded public location, such as the adjacent Potomac Park, the grounds of the Lincoln Memorial, or a nearby alley, to have oral or anal sex. Sometimes they would go to a downtown hotel or to the other man's home to be certain of privacy, but rarely to Alexander's residence because he lived with one of his brothers, who was unaware of his sexuality. ${ }^{19}$ If Alexander was uncertain of the man's intentions, he would often remain in the Square and limit the relationship at most to mutual masturbation, apparently because of the greater risk of being apprehended by the city or park police in such a visible location and the possibility that the man himself could be an undercover officer.

Alexander's concerns about the police were well-founded. As in New York City, the growing number of men cruising in Washington's parks in the late nineteenth and early twentieth centuries prompted authorities to increase surveillance and arrests. ${ }^{20}$ In the 1890s, the Chief of Engineers for the US Army, which oversaw public buildings and grounds in the capital, installed lighting around the Washington Monument and other park areas "in the interest of morality" and began to increase the number of US Park Police officers patrolling at night. ${ }^{21}$ The allocation of additional park personnel, however, was a gradual process, and staffing remained sparse in some parks well into the twentieth century. For example, there was no regular night watch in Franklin Park and Lafayette, McPherson, and Farragut Squares in 1905, and only two park police officers had been assigned to these areas a decade later - and then just until midnight. ${ }^{22}$ But in the absence of substantial federal park personnel, more extensive surveillance was provided by Washington's Metropolitan Police Department, particularly in Lafayette Square. Cruising there in 1922 and 1923, Alexander repeatedly encountered a plain-clothed officer whom he named "the Sneak" for the way that the detective would spy upon him and other men and often follow them.

Although Alexander was never arrested, he did have to cope with the constant threat of being apprehended. At the turn of the century, when Congress converted Washington's common-law statutes into a criminal code, it established sodomy as a felony punishable by up to five years in prison. Faced with the possibility of a long jail sentence and the publicity of a trial, most defendants pled guilty to simple assault, a misdemeanor, and were sentenced to prison terms ranging from a few months to two years. Similarly, individuals 
who were charged with indecent assault often tried to pay a fine or forfeit collateral, but many had no choice but to stand trial. They typically received several months in the city's workhouse or jail. ${ }^{23}$

When the police did not have enough evidence to charge people with sodomy or indecent assault, they still made cruising difficult through continual harassment. One night in Lafayette Square, for instance, the Sneak tried to scare Alexander by sitting on a bench directly across from him and staring. ${ }^{24}$ To try to avoid the undercover officer, Alexander traveled a few weeks later to Farragut Square, a nearby park on Connecticut Avenue. But, as he sat in the Square, the Sneak stopped in front of him, forcing Alexander to look at him and be reminded of the threat posed by the police. The move had the desired effect; Alexander "sat fuming and cursing for the next fifteen minutes just thinking about that contemptible beast." 25

In addition to spying upon men in the city's parks, the local police also seem to have spread rumors about people whom they suspected of pursuing same-sex relationships. Alexander complained bitterly that an officer patrolling Pennsylvania Avenue near Lafayette Square had "set the tongues of all the business neighborhood over there wagging" about him, resulting in a number of the shop owners beginning to treat him with derision. As a consequence, he felt compelled to stop patronizing his regular cafeteria, newspaper vendor, and cigar store and to avoid the whole area as much as possible. His reaction suggests the profound impact that such discrimination had on him:

To think that $I, I$ the innocent little bashful, shy, quiet good child who was, should now be regarded as a criminal by the police, be watched and spied upon, tormented and persecuted and made utterly miserable. ${ }^{26}$

Already self-conscious, Alexander was made even more uneasy by these harassing tactics. A "horrid feeling of being watched, spied on and derided" would cause him, at times, to sit on the most unlit benches, to traverse only the outer paths of Lafayette Square, to take circuitous routes to and from the park, and even to "[hide his] face at the approach of each passerby." 27 Repeated instances of surveillance in 1923 meant that just the sight of a police officer looking at him would "[throw Alexander] right back into that morass of morbid maniacal self-consciousness ... that [he] had just succeeded in struggling out of." 28 In exasperation, he went to the parks less and less frequently in subsequent years.

The police, however, were not the only danger that Alexander and other men faced in cruising. Although he was reluctant to write much about the experiences, on at least two occasions Alexander was robbed by men he met. In 1922, a man whom he brought home with him stole about nine dollars worth 
of stamps from the trunk of his younger brother. A robbery two years later was more costly; Alexander lost twenty dollars and his watch and chain. ${ }^{29}$

\section{Segregated social sites: theatres, clubs, and restaurants}

Another drawback of cruising in Washington parks, of course, was the fact that it could only be done for part of the year. When it became too cold outside to sit in Lafayette Square, Alexander and other men had to pursue different methods for meeting potential sexual partners; one of the most popular options was frequenting the city's motion picture and burlesque houses. For Alexander, theaters had the same attraction that the Square did in the summer, namely "the opportunity for adventure, for amorous intrigue, even though of the mildest sort usually, with other males." ${ }^{30}$ The amount of time he spent in both cruising areas was also similar. Going nightly to theaters became "a craze" for him, "just like the Lafayette habit in [the] summer but more costly." 31

Alexander regularly cruised a number of downtown theaters, ranging from vaudeville houses such as Keith's Theater to some of Washington's most elegant movie palaces and auditoriums such as the National Theater. But no matter where he went, his method was the same. Like men who pursued same-sex relationships at that time in New York City, Alexander would sit next to a young man who was by himself (or occasionally between two men) in the balcony, since upper galleries were typically less supervised by ushers and had a smaller audience than the main floor. ${ }^{32} \mathrm{He}$ would then try to indicate his intentions subtly by brushing against the other person's leg or arm. Even in most balconies, though, the majority of theatergoers were there to see the movie or performance. Consequently, Alexander's "winter style theater intrigues" were often limited to subtle caressing, and a number of his advances were unsuccessful. ${ }^{33}$

For men who desired more than touching, theaters in Washington's tenderloin district afforded greater sexual opportunities. In the 1920s, the three blocks of Ninth Street north of Pennsylvania Avenue were renowned for burlesque and vaudeville theaters and cheap hotels catering to a variety of sexual interests. Men who were looking for same-sex relationships frequented the Strand, a Ninth Street movie palace that, according to Alexander, became known as a prime cruising area soon after it opened in 1916. Alexander began regularly going to the Strand in the early 1920s, and noted one night in 1923 that he masturbated a man in its balcony. ${ }^{34}$

African Americans also sat in the balconies of the city's less respectable theaters, but except for those interested in same-sex relationships, they did not do so willingly. Segregation prevented them from sitting elsewhere in tenderloin theaters, and more popular downtown movie houses denied them admittance altogether beginning in the early twentieth century. Faced with such dis- 


\section{Beemyn}

crimination, most African Americans chose to frequent only theaters in the Black community, including the renowned Howard and Lincoln Theaters. But for Black men attracted to people of the same sex, such places did not provide enough anonymity for cruising. Since they lived and often worked in the same neighborhoods in which these theaters were located, it was very likely that relatives, neighbors, and coworkers would be in the audience as well. ${ }^{35}$

Like theaters, most clubs and restaurants in the capital were divided along racial lines in the early twentieth century. Many US cities with extensive samesex sexual communities prevented African Americans from patronizing clubs and restaurants outside of Black neighborhoods. But racism in Washington also meant that whites, including individuals who were attracted to others of the same sex, did not frequent establishments in Black neighborhoods in the 1920s and 1930s, as was the case in northern cities such as New York and Chicago. ${ }^{36}$ Instead, white Washingtonians who pursued same-sex relationships often sought to minimize the possibility of being recognized by people they knew by patronizing more secluded downtown clubs and restaurants.

One such restaurant during Prohibition was the Krazy Kat, which Alexander described as "a 'Bohemian' joint in an old stable up an alley" near Franklin Park. Its clientele included white men attracted to other men and "artists, musicians, atheists, [and] professors." 37 Although Alexander never went there himself, being "afraid [he'd] make a fool of [himself] by [his] backwardness," he did provide directions one night in Lafayette Square to two white youths from Philadelphia who had asked him about the restaurant. The fact that out-of-town men knew of the Krazy Kat, as well as had heard about the popularity of the park for cruising, demonstrates that, despite many establishments being hidden from public view, white men attracted to others of the same sex were able to create a social world that newcomers could find and enter without much difficulty. ${ }^{38}$

With the ending of Prohibition, bars could legally open in Washington, and a number of the new clubs became more well-known as places where men, and sometimes women, could meet potential same-sex partners. For Black men who were "in the life," the most popular site in the 1930s was the Republic Gardens, a U Street restaurant which held drag shows in its back-room bar. Some of its entertainers were featured as "homosexuals," which contributed to the restaurant's reputation among men attracted to other men, but also increased the likelihood of a raid. Police interference seems to have been rare, though, because the performers themselves watched the front door through a small window by the piano and warned patrons if they saw an officer entering the restaurant. ${ }^{39}$

For the owners and clientele of some of the new establishments, the police were less of a concern than hostile members of the military. This was especially the case with the Showboat, a segregated basement bar located three 
blocks from Lafayette Square, where soldiers caused so many conflicts that the proprietor took the unusual step of appealing to the Army to declare the bar off limits to military personnel. In an interview with the Army's regional headquarters soon after the bar opened in 1936, owner George Sachlis stated:

About $75 \%$ of my customers are what are known as "Queer." They make no trouble but only ask to be left alone. We seat them all together on the other side of a dividing rail in the middle of the taproom. All other patrons are put on the other side of the partition. The soldiers and sailors, particularly soldiers, keep making remarks to the other customers but are very profane and insulting. The "Queer" customers do not fight but they get up and leave. This usually causes disturbances and loss to business.

After confirming that many soldiers had visited the Showboat and engaged in abusive and violent behavior toward its "Queer" and female patrons, the Army readily agreed to the request. In fact, had they known that "the Showboat was frequented by degenerates," local commanders would likely have declared it off limits, even if the owner objected. ${ }^{40}$ In this case, though, both Sachlis and the Army were satisfied with the effects of the banning order, as members of the armed forces rarely patronized the bar during the subsequent ten years that it remained in business. ${ }^{41}$

\section{"Young Pansy, Go North": attending drag balls in and away from the city}

Although Black men in Washington interested in same-sex relationships were excluded from many of the city's theaters, restaurants, and clubs, they did organize and participate in some of the country's earliest known drag balls. One such gathering, held on New Year's Eve in 1885, was documented by the Washington Evening Star because a participant, "Miss Maud," was arrested when returning home the following morning. Dressed in "a pink dress trimmed with white lace, with stockings and undergarments to match," the thirty-yearold Black drag queen was charged with vagrancy and sentenced to three months in jail, even though the judge "admired his stylish appearance."42

The Star's depiction of the event as a comical spectacle involving an effeminate man stood in sharp contrast to the menacing portrayal of a subsequent local "drag dance" by Charles H. Hughes, a St. Louis physician. Included as a postscript to an 1893 medical journal article, his second-hand account was in keeping with the cultural image of Black men as savage degenerates with overdeveloped sexual drives: 
150 Beemyn

In this sable performance of sexual perversion all of these men are lasciviously dressed in womanly attire, short sleeves, low-necked dresses and the usual ball-room decorations and ornaments of women, feathered and ribboned headdresses, garters, frills, flowers, ruffles, etc., and deport themselves as women. Standing or seated on a pedestal, but accessible to all the rest, is the naked queen (a male), whose phallic member, decorated with a ribbon, is subject to the gaze and osculations in turn, of all the members of this lecherous gang of sexual perverts and phallic fornicators.

Making "this strange libidinous display" even more horrifying to Hughes was the fact that these Black men, among them "cooks, barbers, waiters, and other employees of Washington families," served and interacted with leading members of white society. ${ }^{43}$

By the 1890 s, men attracted to other men had also begun organizing their own drag events in New York. According to George Chauncey, these drags drew enormous numbers of Black and white participants and spectators, especially during the late 1920 s and early 1930 s, when at least a half dozen events were staged each year in some of the city's largest and most respectable halls. ${ }^{44}$ By 1930, public drag balls were also being held in Chicago, although on a smaller scale and in less reputable locations. ${ }^{45}$ Organizers in both cities would obtain a license from the police to prevent participants from being arrested for cross-dressing, and uniformed officers would even provide crowd control outside the halls and help ensure order inside.

The largest and best-known annual drag event in New York, and probably the country, in the early twentieth century was Harlem's Hamilton Lodge ball. During the early 1930s, it attracted nearly seven thousand dancers and onlookers, most of whom were African American, and received extensive coverage in the city's Black newspapers. Some of the earlier accounts of what became known among Harlem residents as the Faggots Ball ridiculed the participants, but by the $1930 \mathrm{~s}$, most press reports assumed a more admiring tone. Like many straight people who attended the balls, the newspapers treated the event as a spectacle, commenting on the appearance of the drag queens and their ability to present as women. ${ }^{46}$

While drag balls in the Black communities of New York and Chicago were becoming enormously popular and being sanctioned by the police and press in the 1930s, large, public drag events could not be held in Washington because of the hostility of institutional authorities. A local group, the Impersonators' Club, organized a drag ball in 1934, but the police banned the event immediately before it was to have begun. About 1500 people who had hoped to participate were turned away to the jeers of a crowd that gathered to watch. When 
some onlookers began to assault and chase the drag queens, seeking to tear off their clothes, police officers "stood by and did nothing to stop the attacks." 47 The Washington Afro-American, which provided sensational coverage of the event, also supported the violent reaction, arguing in an editorial entitled "Young Pansy, Go North" that "they had it coming to them, and therefore, may blame no one but themselves." The newspaper concluded:

It is one thing to be sympathetic with long-haired men and with women who wish to wear pants. It is quite another thing to tolerate a display of degeneracy in dance halls in order to attract the public.

Yet these brethren or "sisters," unwanted in Washington, will be welcomed in New York where over a thousand of the neuter gender of both races will dance this week at the annual dance of the Hamilton Lodge.

The pansy motto should be: "Young lady, go North." 48

Ironically, Black drag queens had already been going North for years, frequenting not only the Hamilton Lodge balls, but also the annual drags sponsored by Baltimore's Art Club during the 1920s and 1930s. In fact, in the weeks following the police's ban, African Americans from the capital attended both the New York ball and a similar one held in Baltimore, where a Washingtonian won first prize for her costume. Thus, rather than limiting the sexual and gender expression of the city's Black drag queens, the crackdown served to enhance their visibility away from the capital and added importance to a long-standing social tradition. ${ }^{49}$

\section{Rooming houses and apartments}

As in the public social realm, segregation in housing severely restricted where African Americans could live in Washington and limited opportunities for interracial mixing. But both Blacks and whites attracted to others of the same sex were able to take advantage of the growing number of rooming houses and apartment buildings in the capital during the early 1900s. Rooming houses fostered an atmosphere of greater sexual freedom by often removing young men and women from familial supervision and placing them in neighborhoods in which single lodgers predominated. The managers and owners of rooming houses sometimes sought to institute themselves as replacements for parental authorities, but a high turnover rate in Washington's furnished room districts meant that most rooming house keepers were anxious to hold onto any tenants who could meet their financial obligations, and thus refrained from becoming involved in their roomers' sexual lives. ${ }^{50}$ Others simply accepted, or at least 
were accustomed to, same-sex sexuality. When Jack Frey and Peter Morris were living in a rooming house in the early $1950 \mathrm{~s}$, the owner did not seem surprised to discover them in bed together one night. Not only did she refrain from evicting them, but they remained good friends until her death. ${ }^{51}$

Two women or men living together in a rooming house often did not arouse suspicion because it was common for lodgers to have roommates. Sometimes rooming-house keepers even brought couples together, albeit inadvertently, through the longstanding practice of assigning rooms to unmarried people of the same sex. "Dusty" Keyes met his partner of 47 years this way. When he arrived in Washington in 1946, he was sent by his employer, the Veteran's Administration, to a nearby rooming house, where he immediately fell in love with the man he was placed with. ${ }^{52}$

The construction of numerous apartment hotels and houses in Washington and other US cities during the late nineteenth and early twentieth centuries offered people with higher incomes the opportunity to have much more privacy, anonymity, and space than could be provided by rooming houses. As noted by George Chauncey, apartments became especially popular among middleclass women and men who were attracted to others of the same sex. Not only did apartments allow couples to live together with less fear of discovery, but they also enabled tenants to host parties and private gatherings that served as an alternative to more risky public meeting places. ${ }^{53}$ In 1921, Jeb Alexander met "Hugh," a thirty-year-old man living in a small, two-bedroom apartment near downtown, who invited "the flower of Washington" to his rooms because "the parks were not any place to go." About a dozen men were "in the little circle of kindred spirits that revolved around him and his apartment," including a sixty-year-old man and several youths in their late teens. ${ }^{54}$

The earliest apartment houses in Washington were built downtown and in all-white neighborhoods, but shifting residential patterns meant that some of these buildings had mostly Black tenants by the mid-1920s. At the same time, developers began to construct apartments explicitly for African Americans, recognizing that they could "[be] rented as fast as they [could] be built." For African Americans attracted to others of the same sex, the appeal of apartment living was the same as it was for their white counterparts: it enabled "much unconventional behavior," since neighbors "[could] not detect anything 'improper' in the frequent 'coming and going' that characterize[d] the life of its occupants." According to a study of Black housing patterns, it was becoming popular in Washington's Black neighborhoods for "three or four young men" or for "insurgent women seeking ultra-independence and Bohemianism" to rent an apartment together during the $1920 \mathrm{~s} .{ }^{55}$

The lax social world of rooming houses and apartment buildings greatly concerned nineteenth-century moral reformers, who recognized a danger in unmarried youth, many of whom were recent migrants to the city, being able to 
mingle without familial supervision. They responded by trying to provide this oversight, thereby hoping to protect young men and women from the perceived evils of city life. Some reform groups sponsored boarding houses to provide an alternative to rooming houses, while others sought to place some of the newcomers with local families. The most successful reform organization, the Young Men's Christian Association (YMCA), offered access to reading rooms, evening classes, swimming pools, gymnasiums, and eventually dormitory rooms to individuals who, in the words of the constitution of the main Washington, DC branch, were "of good moral character." 56

Although many Ys provided emergency housing during periods of high unemployment, most facilities did not immediately offer long-term housing. In part, this was due to the fact that renting out store and office space was a better revenue-generating device for financially strapped Associations, and most early facilities simply did not have enough room for both purposes. Some leaders also initially feared that what they saw as the sexually immoral atmosphere of rooming houses would be repeated in YMCA dormitories. But as shaping the moral development of young men was its primary mission, Ys constructed new buildings in the early twentieth century that could accommodate dormitory rooms. The number of beds in Association facilities increased more than fivefold between 1910 and $1920 .^{57}$

Washington's YMCA began offering rooms for both lodgers and members when it opened its Central Building two blocks from Lafayette Square in 1905. Five years later, 185 white men were living in the building, and work had been completed on a new facility to serve African Americans, which was entirely autonomous from the downtown branch. ${ }^{58}$ For YMCA leaders who believed that the seeming immorality of rooming houses would spread to their newly built dormitories, the Association's facilities in the nation's capital did nothing to allay their concerns. The Central Building became well known as a site for men to meet other men for sex by the 1920 s, and its proximity to Lafayette Square only added to the branch's popularity. Alexander lived at the downtown YMCA for five years beginning in 1922 and encountered many men there who pursued same-sex relationships, including "Dash" and several others who would become lifelong friends.

In Take the Young Stranger by the Hand: Same-Sex Relations and the $Y M C A$, John Donald Gustav-Wrathall argues that Ys were an ideal setting for same-sex sexual activity because they were easily accessible, male-only spaces that were largely free of police surveillance and staff supervision. ${ }^{59}$ Even after a 1912 police raid on the Portland, Oregon, YMCA created a national scandal, supervision remained lax and cruising continued unimpeded at most branches. Many managers seem to have been willing to look the other way, provided that same-sex sexual activity did not become so conspicuous as to risk another scandal. 


\section{Beemyn}

In an apparent attempt to keep cruising from becoming too rampant in the dormitory and steam and locker rooms of the downtown Washington YMCA, the house manager evicted individuals who were too obvious in pursuing samesex sexual relationships, including two of Alexander's friends. Dash, for example, was forced to leave the $Y$ in 1930 when he tried to have a guest spend the night in his room. The manager, evidently presuming that the man was a sexual partner, gave him three days notice. The head of the building agreed with this decision, noting that Dash "seemed out of sympathy with the [YMCA's] ideals and its character-building program."60

The administrators were not the only ones at Washington's main YMCA branch who reacted harshly to individuals suspected of being involved in samesex relationships. Alexander noted in a 1924 diary entry that a friend of one of his brothers - unaware of Alexander's sexuality - announced that "a damn fairy" he saw in the lobby "ought t'have been taken out and frailed [the] hell out of." 61 It was incidents like these that led Alexander to decide to leave the $Y$ for a rooming house several blocks away, on the north side of Lafayette Square.

\section{Conclusion}

In Gay New York, George Chauncey documents how white men interested in same-sex relationships developed residential and commercial enclaves in the Bowery, Greenwich Village, and Times Square in the late nineteenth and early twentieth centuries. ${ }^{62}$ African Americans, who were denied access to many of the restaurants and clubs in these neighborhoods, created an extensive samesex sexual community in Harlem that was also patronized by many whites. In contrast, white men in Washington seem to have largely avoided the city's Black neighborhoods. As demonstrated by Alexander's experiences, the sexual geography for white men in the nation's capital was concentrated downtown. In this section of the city, they could live and entertain in apartment and rooming houses and meet sexual partners in theaters, parks, and more secluded bars and restaurants. Moreover, many were also employed downtown, often by the federal government. Like Alexander, most of his friends worked in federal agencies, including Dash and Isador, who held positions in the State Department.

Black men attracted to others of the same sex carved out a place for themselves in Washington's Black neighborhoods, but they also established a presence in downtown parks and some tenderloin theaters. Despite segregation, the racist attitudes of men like Alexander, and the prohibition on holding large, interracial drag balls, African Americans who were in the life occupied some of the same social spaces as whites. Thus while Black and white men who cruised other men in the nation's capital created separate sexual worlds, these 
worlds were not wholly divided by the color line.

\section{Notes}

${ }^{1}$ All information and quotations from "Jeb Alexander" will be taken directly from his diaries, which I viewed with the gracious help of Ina Russell, his niece. I do not use her published version of the diaries (Jeb and Dash: A Diary of Gay Life, 1918-1945 [Boston: Faber and Faber, 1993]) because of differences in wording from the original and a lack of historical accuracy. Jeb and Dash regularly combines events that occurred at different times into a single day; creates composite characters for most of the people closest to Alexander, including "Dash"; and invents and embellishes diary text to make a clearer, simpler narrative. But in order to maintain consistency and confidentiality, I will use the pseudonyms of the published version.

${ }^{2}$ Other published diaries of men who pursued same-sex sexual relationships in the early twentieth century include Earl Lind (Ralph Werther/Jennie June), Autobiography of an Androgyne (1918; New York: Arno Press, 1975) and The Female Impersonators (1922; New York: Arno Press, 1975) and Donald Vining, A Gay Diary, vol. 1, 1933-1946 (New York: Pepys Press, 1979).

${ }^{3}$ Jeb Alexander, diary entry, 11 August 1923.

${ }^{4}$ A law passed in 1872 banned discrimination in the city's public facilities, but it was largely ignored by the late nineteenth century, as white hostility toward African Americans increased, and by the turn of the century it was quietly removed from Washington's statutes. Constance McLaughlin Green, The Secret City: A History of Race Relations in the Nation's Capital (Princeton, NJ: Princeton University Press, 1967); Segregation in Washington: A Report of the National Committee on Segregation in the Nation's Capital (Washington, DC: The National Committee on Segregation in the Nation's Capital, 1948); Mary Church Terrell, $A$ Colored Woman in a White World (Washington, DC: Ransdell, 1940).

${ }^{5}$ George Chauncey, Gay New York: Gender, Urban Culture, and the Making of the Gay Male World, 1890-1940 (New York: HarperCollins, 1994); David K. Johnson, "The Kids of Fairytown: Gay Male Culture on Chicago's Near North Side in the 1930s," and Allen Drexel, "Before Paris Burned: Race, Class, and Male Homosexuality on the Chicago South Side, 1935-1960," in Creating a Place for Ourselves: Lesbian, Gay, and Bisexual Community Histories, ed. Brett Beemyn (New York: Routledge, 1997), 97-118 and 119-44.

${ }^{6}$ John Howard, Men Like That: A Southern Queer History (Chicago: University of Chicago Press, 1999), xiv.

${ }^{7}$ Alexander, 10 June 1923, and 1 September 1921.

${ }^{8}$ Ibid., 12 August 1923.

${ }^{9}$ For someone who often felt uncomfortable approaching other men, it is surprising that Alexander would catalog his sexual encounters so openly. He did write these pages in pencil, while the rest of the diary was in pen, presumably to be able to erase them later if needed. He also kept his diary locked in a trunk. But the fact that he would reveal his sexual practices at all, as well as the real names of some of his sexual partners, sug- 


\section{Beemyn}

gests that Alexander's reluctance cannot simply be attributed to uneasiness about his sexuality.

${ }^{10}$ Alexander, 12 May and 19 May 1923.

${ }^{11}$ Jonathan Ned Katz, Gay American History: Lesbians and Gay Men in the USA (New York: Harper and Row, 1976), 385-97.

12 For example, in a 1923 entry, Alexander describes having an affair with "a gentle, winsome lad" of seventeen who "was well dressed in a gray light suit, soft white shirt, and small black bow tie." Giving into romanticism, he concludes the entry: "we lay in each other's arms, my love and I, while the full moon beamed from a spacious sky and the cool night breezes blew, rustling our hair, and the black trees stood like sentinels against the silvery rolling grounds" (28 June). At the other extreme, he wrote a month earlier: "A stout spectacled idiot of 45 flopped down at the other end of my bench. $\mathrm{He}$ tried twice to make conversation but I said merely 'uh-huh' and continued to look away with my back toward him. He presently left ..." (29 May).

${ }^{13}$ Alexander, 7 September 1923.

${ }^{14}$ Irving C. Rosse, "Sexual Hypochondriasis and Perversion of the Genesic Instinct," Journal of Nervous and Mental Disease 17 (November 1892): 806. Cited in Katz, Gay American History, 42.

${ }^{15}$ Alexander, 10 September 1922. Alexander engaged in this practice with other groups as well. He labeled an area of the park "Sailor's Row" because its benches were frequented by military personnel.

${ }^{16}$ Ibid., May 18, 1923.

${ }^{17}$ Annual Report of the Chief of Engineers for 1886 (Washington, 1887), 2078.

18 "Record of Arrests Made by Watchmen of Public Buildings and Grounds, 26 April 1899-28 April 1920," Records of the Park Police Division, Office of Public Buildings and Public Parks of the National Capital, Record Group 42, National Archives, Washington, DC. For the application of the indecent assault charge to same-sex sexual activity in Washington, see Rosse, "Sexual Hypochondriasis and Perversion of the Genesic Instinct," 806.

${ }^{19}$ Alexander, 30 June 1923.

${ }^{20}$ Chauncey, Gay New York, 141, 183. Men who cruised in public spaces in Chicago apparently had less fear of arrest than men in Washington and New York until the police there launched a crackdown in the late 1930s. Johnson, "The Kids of Fairytown," 112.

${ }^{21}$ Annual Report of the Chief of Engineers for 1895 (Washington, 1896), 4141; Barry Mackintosh, The United States Park Police: A History (Washington: National Park Service, 1989), 12, 17.

${ }^{22}$ Annual Report of the Chief of Engineers, US Army, 1905 (Washington, 1906), 2669; Annual Report of the Chief of Engineers, US Army, 1915 (Washington, 1915), 1685-86.

23 "District of Columbia Supreme Court, Criminal Case Files, 1863-1934," Record Group 21, National Archives; "Record of Arrests Made by Watchmen of Public Buildings and Grounds," National Archives; "Changes in Sex Laws with 20-Year Penalty Are Prepared by Fay," Evening Star, 14 December 1947, A7; Liza Mundy, "The Scarlet S: DC's Sodomy Law from Top to Bottom," Washington City Paper, 26 February 1993, 8; Lou Chibbaro, Jr., "Sodomy Law Repealed," Washington Blade, 21 September 1993, 13. 
${ }^{24}$ Alexander, 14 June 1923.

25 Ibid., 4 July 1923.

26 Ibid., 11 August 1923.

${ }^{27}$ Ibid., 11-13 August, 16 August, and 19 September 1923.

${ }^{28}$ Ibid., 18 August 1923.

${ }^{29}$ Ibid., 17 August 1922, and 3 May 1924.

${ }^{30}$ Ibid., 22 March 1923.

31 Ibid., 9 April 1923.

${ }^{32}$ Chauncey, Gay New York, 194.

${ }^{33}$ Alexander, 11 April 1923. Several decades earlier, Charles Warren Stoddard, the chair of English literature at Catholic University, had also frequented the balconies of the capital's theaters looking for young men and, like Alexander, he remained largely unable to fulfill his sexual longings. In Stoddard's case, his actions were limited as well by his position and his fixation on finding "a Kid" to share his life. "The town is full of attractions," he lamented in 1892. "I never go into it but my heart yearns now and again." Roger Austen, Genteel Pagan: The Double Life of Charles Warren Stoddard, ed. John W. Crowley (Amherst: University of Massachusetts Press, 1991), 124.

${ }^{34}$ Alexander, 17 January 1923.

${ }^{35}$ Although the Howard Theater sponsored drag shows by the Jewel Box Revue, a Miami-based touring company, in the 1940s and 1950s, the audience still seems to have been primarily heterosexual. Talk by Samuel Delany at the Modern Language Association Conference, Washington, DC, 1996.

${ }^{36}$ Chauncey, Gay New York, 246-47; Drexel, "Before Paris Burned," 126.

${ }^{37}$ Alexander, 23 July 1920.

${ }^{38}$ Alexander, 27 August 1921. The extent to which Lafayette Square was renowned as a cruising location is shown by the fact that one of the men had heard about the park while he was in the Virgin Islands.

39 Smith, "Walk on Washington," 123; E. Franklin Frazier, Negro Youth at the Crossways: Their Personality Development in the Middle States (Washington, DC: American Council on Education, 1940), 284; "Female Impersonators in Washington Show," Washington Afro-American, 25 September 1937, 8.

40 George Sachlis to the Adjunct General, US Army, 24 November 1936, First Lieutenant Forrest Caraway to the Commanding General, Washington Provisional Brigade, 25 November 1936, and General Orders No. 4, Washington Provisional Brigade, 1 December 1936, all in Third Corps Area General Correspondence, Record Group 394, National Archives, Washington, DC.

${ }^{41}$ Personal interview with "Haviland Ferris," 16 May 1994, 7.

42 "In Female Attire: A Man Caught Masquerading in Woman's Garb Sent to the Workhouse," Evening Star, 1 January 1886. My thanks to Will Roscoe for pointing this story out to me.

${ }^{43}$ C.H. Hughes, "Postscript to Paper on 'Erotopathia"," Alienist and Neurologist 14 (October 1893): 731-32.

44 Chauncey, Gay New York, 293.

45 Drexel, "Before Paris Burned," 131.

46 Chauncey, Gay New York, 257-59. For coverage of the New York balls, see, for 


\section{Beemyn}

example, "Hamilton Lodge Ball an Unusual Spectacle," New York Age, 6 March 1926, 3; "Masquerade Ball Draws 5,000 People," Amsterdam News, 20 February 1929, 2; "Snow and Ice Cover Streets as Pansies Blossom Out at Hamilton Lodge's Dance," Amsterdam News, 28 February 1934, 1-2; "Harlem and Park Avenues Step Out Together at Twilight Folks' Ball," Washington Afro-American, 5 March 1938, 19.

47 "The Impersonators' Ball, February 1st," Washington Afro-American, 27 January 1934, 4; "DC Police Halt Pansies' Dance," Washington Afro-American, 10 February 1934, 1-2.

48 "Young Pansy, Go North," Washington Afro-American, 17 April 1934, 12.

${ }^{49}$ On the Baltimore dances, see "'Girls' Had Beards and Heavy Voices at Baltimore Jamboree," Chicago Defender, 15 March 1924, 1; "Men Dance with Male 'Flappers' at Artists' Ball," Baltimore Afro-American, 19 March 1927, 20; "Men Take Women's Places in Annual Art Clubs' Ball," Baltimore Afro-American, 10 March 1928, 8; "They Vied for Honors at Impersonators' Ball," Washington Afro-American, 24 February 1934; "Baltimore and Washington Men in Masquerade Dance," Washington Afro-American, 3 March 1934, 1.

50 Drum Beats: Walt Whitman's Civil War Boy Lovers, ed. Charley Shively (San Francisco: Gay Sunshine Press, 1989), 21; William H. Jones, Recreation and Amusement Among Negroes in Washington, D.C. (Washington, DC: Howard University Press, 1927), 168. For a more extensive discussion of rooming houses, see Joanne Meyerowitz, "Sexual Geography and Gender Economy: The Furnished Room Districts of Chicago, 1890-1930," in Gender and American History Since 1890, ed. Barbara Melosh (New York: Routledge, 1993), 43-71, and Paul Groth, Living Downtown: The History of Residential Hotels in the United States (Berkeley: University of California Press, 1994), 90-130.

${ }^{51}$ Personal interview with Jack Frey and Peter Morris, 22 March 1994, 5.

${ }^{52}$ Chauncey, Gay New York, 154; personal interview with Thomas "Dusty" Keyes, 30 May 1994, 1.

${ }^{53}$ Chauncey, Gay New York, 158-59.

${ }^{54}$ Alexander, 6 July 1921.

${ }^{55}$ William Henry Jones, The Housing of Negroes in Washington, D.C.: A Study in Human Ecology (Washington, DC: Howard University Press, 1929), 135-37.

${ }^{56}$ Meyerowitz, "Sexual Geography and Gender Economy," 56; Chauncey, Gay New York, 154; C. Howard Hopkins, History of the Y.M.C.A. in North America (New York: Association, 1951), 457; Paul Boyer, Urban Masses and Moral Order in America, 18201920 (Cambridge: Harvard University Press, 1978), 116-17; "Constitution of the YMCA of Washington, D.C.," YMCA Archives, Washington, DC.

${ }^{57}$ Boyer, Urban Masses and Moral Order, 117; John Donald Gustav-Wrathall, Take the Young Stranger by the Hand: Same-Sex Relations and the YMCA (Chicago: University of Chicago Press, 1998), 15; Hopkins, History of the Y.M.C.A. in North America, 155, $456-57$.

58 "Guide to the Central Building of the YMCA, Washington, D.C.," "Miscellaneous Historical Clippings File," YMCA Archives, Washington, DC.

${ }^{59}$ Gustav-Wrathall, Take the Young Stranger by the Hand, 142.

${ }^{60}$ Alexander, 27 January 1927; 9 October, 11 October, and 13 October 1930. 
61 Ibid., 20 February 1924.

62 Chauncey, Gay New York, 136. 